\title{
NURSES IN FAMILY PEDIATRIC PRACTICES: A SURVEY OF THE HEALTH PROTECTION AGENCY OF THE METROPOLITAN CITY OF MILAN
}

Abstract

\section{Purpose:}

Primary pediatric care in Italy is guaranteed by family pediatricians, who may have their own private offices or work in group clinics that also have nurses/pediatric nurses in order to enrich their offer of services. The aim of this study was to investigate the activities of nurses working in pediatric practices in order to identify and classify the nursing healthcare services offered by the practices themselves.

\section{Design and study:}

An observational study was conducted including nurses working in the pediatricians' offices who voluntarily agreed to undergo a semi-structured interview. The investigated variables were individual, institutional and organisational. The study sample consisted of 22 nurses with a mean age of $39 \pm 13.3$ years, 16 of whom were pediatric nurses.

\section{Results:}

All of the nurses stated that they had not received suitable training for working outside a hospital, and that they carried out educational, diagnostic/therapeutic, and bureaucratic administrative/support activities. Nine of the nurses working in group pediatric clinics carried out educational activities autonomously, something that the nurses working in individual or associated clinics did not perform. Twenty of the interviewees also provided telephone consultancy, and 11 of the clinics used algorithms as guides.

\section{Conclusions/Practice implications:}

The findings of this study underline the potential of developing the nursing profession at community level. Further studies are desirable in order to extend the investigation of the pediatric nurses' activities implemented at community level in other Italian provinces.

Keywords: nurse, primary pediatric care, pediatric patient care 


\section{NURSES IN FAMILY PEDIATRIC PRACTICES: A SURVEY OF THE HEALTH \\ PROTECTION AGENCY OF THE METROPOLITAN CITY OF MILAN}

Elena Nicoletta Bezze ${ }^{a}$, Daniela Mornirolia ${ }^{a}$, Martina Farnetia ${ }^{\text {, Patrizio Sannino }}{ }^{\mathrm{c}}$, Roberto

Marinello $^{\text {b }}$, Maria Enrica Bettinellie, Germana Santini ${ }^{a}$, Laura Plevania ${ }^{\mathrm{a}}$, Paola Marchisio ${ }^{\mathrm{d}, \mathrm{e}}$,

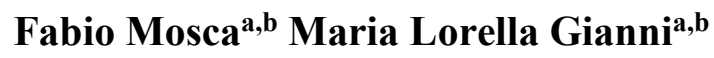

a. Neonatal Intensive Care Unit, Fondazione IRCCS Ca' Granda Ospedale Maggiore, Policlinico, Via Commenda 12, 20122, Milan, Italy

b. Department of Clinical Sciences and Community Health, University of Milan, Via Commenda 19, Milan, Italy

c. Fondazione I.R.C.C.S. Ca Granda Ospedale Maggiore Policlinico, Direzione Professioni Sanitarie, Via Francesco Sforza 28, 20122, Milan, Italy

d. University of Milan, Department of Pathophysiology and Trasplantion, Via Francesco Sforza 35, 20122 Milan

e. Pediatric Highly Intensive Care Unit, Fondazione IRCCS Ca' Granda Ospedale Maggiore Policlinico, Via Commenda 9, 20122, Milano, Italy

${ }^{*}$ Corresponding author:

Elena Nicoletta Bezze, Neonatal Intensive Care Unit, Fondazione IRCCS Ca' Granda Ospedale Maggiore Policlinico, Via Commenda 12, Milano 20122, Italy

Phone: +390255034348; Fax: +390255032429; E-mail: elena.bezze@policlinico.mi.it 


\section{NURSES IN FAMILY PEDIATRIC PRACTICES: A SURVEY OF THE HEALTH 2 PROTECTION AGENCY OF THE METROPOLITAN CITY OF MILAN}

3 PURPOSE

4 As indicated in the European Health Report 2012, the significant demographic and epidemiological

5 changes that have taken place over the last few decades have unequivocally highlighted the need to

6 promote health, prevent diseases and provide more than simple healthcare (The European Health

7 Report 2012: Charting the way to well-being, 2012). The widely documented reduction in the

8 duration of hospitalization, early discharges, the increased incidence of chronic degenerative

9 diseases also in the pediatric setting and the adverse effects of hospitalization on children and their families all underline the need to review healthcare models and redefine the responsibilities of local healthcare professionals (Document of the Conference of Regions. The White Book on children's health 2011,2012 ). One solution may be to implement primary healthcare measures aimed at actively promoting health and strengthening personal resources such as self-care and family learning and individually accessible social resources, particularly in the case of people affected by chronic diseases or disabilities (Il sistema delle cure primarie, 2010). In this context, the decisive role of nurses is widely supported in various international and European directives, including the "Health for All" project of the World Health Organization (Asvall, 2000), as well as several published scientific studies (Rocco et al., 2017; Martínez-González et al., 2015) whose findings suggest that appropriately trained nurses are capable of obtaining primary care results that are as good as those achieved by physicians, or even better in certain investigated areas. A recent review by Laurant and colleagues (Laurant et al., 2018) has demonstrated that nurse-led primary care resulted in a higher satisfaction level compared to doctor-led practice. The same improvement was found regarding chronic patients' health status (i.e., blood pressure control, chronic pain in rheumatological patients). Moreover, nurse-led primary care was found to offer a longer consultation time and to promote the patient's compliance, resulting in a higher attendance of return visits. 
However, despite considerable efforts in standardizing nurses' education in different settings, the variety of regulatory bodies of each country and the broad significance of Advanced Practice Nurse (APN) and Advanced Paediatric Nurse Practitioners (APNPs), undermines the creation of a globally acknowledged APN's scope of practice (Kooienga \& Carryer, 2015).

The organization of primary pediatric care in Europe varies from country to country, but pediatricians are generally considered second-level specialists. In Italy, pediatric care is guaranteed by family pediatricians, who represent a primary national resource for protecting children and adolescents' health. Every Italian child has a right to treatment by a specialist National Health Service pediatrician from birth until the age of 14 years (16 in the case of chronic disease or particularly delicate clinical conditions). It is compulsory to have children followed by a pediatrician up to the age of six years, whereas parents can choose to have their children aged 7-14 (or 16) years followed by a pediatrician or general practitioner (Marinello \& Scarazatti, 2011). In addition to solo practices, pediatric healthcare's local organization also increasingly involves various associative forms as described in the National Collective Agreement of 2000 (Accordo Collettivo Nazionale per la disciplina dei rapporti con i medici specialistici

Pediatri di libera scelta, 2000) which have been divided in pediatric group practices, associations, and networks. These now account for $60 \%$ of practices and are an essential and innovative means of providing higher service levels and facilitating citizen/pediatrician relationships (Le cure primarie nel nuovo assetto organizzativo e funzionale del SSN, 2013; Regolamento concernente l'individuazione della figura e del relativo profilo professionale dell'Infermiere, 1994) as, in addition to administrative/bureaucratic personnel, also involve the collaboration of nurses/pediatric nurses who can enrich the services offered by a clinic and improve the quality and accessibility of primary pediatric care (Accordo Collettivo Nazionale per la disciplina dei rapporti con i medici specialistici Pediatri di libera scelta, 1999).

A multicentre study by Van Esso (Van Esso et al., 2010) has explored differences in pediatric primary care across Europe: $64 \%$ of the pediatric clinics included in the survey were staffed by a 

3

4

median of one nurse for every pediatrician or general practitioner (with a range from 1 to 7 ). A study conducted in Denmark highlighted the role of APNPs in promoting holistic and familycentered practice through educational interventions (Würtz et al., 2019) while research within a Spanish setting, demonstrated the usefulness of algorithms for nurse care management of children with acute minor illnesses in primary care (Fabrellas et al., 2015).

However, nurses' working activities and beneficial role within the primary care system, although widely investigated in the other European countries, have been poorly explored within the Italian setting. This study aimed to investigate the working activities of these nurses in order to identify and classify the nursing care provided by the clinics in which they work.

\section{DESIGN AND METHODS}

The institutional review board of the Fondazione IRCCS Ca' Granda Ospedale Maggiore

Policlinico, Milano, approved the study.

\section{Setting}

The study involved the individual or associative practices of primary care pediatricians

registered with the Health Protection Agency of the Metropolitan City of Milan.

\section{Inclusion criteria}

The study population consisted of nurses/pediatric nurses working in the practices of primary care pediatricians.

\section{Exclusion criteria}

The pediatricians themselves and any other professionals (i.e., physiotherapists, secretaries, psychologists) working in the same practices.

\section{Method}

All primary care practices registered with the Health Protection Agency of the Metropolitan City of Milan were contacted and asked whether a nurse or pediatric nurse was employed in the practices. Subsequently, the nurses were asked to take part in the study. As participation was voluntary, the project was described to the nurses who were asked to consent to the interviews under the guarantee 
of anonymity. Nurses who agreed to participate attended semi-structured interviews conducted in their place of work, in August and September 2018.

Each interview lasted around 30 minutes, was conducted by the same researcher, recorded and transcribed. The questionnaire was divided into two parts: the first part consisted of 5 close-ended questions regarding the essential characteristic of the practice (i.e., associative or individual study, number of nurses working in the practice, number of children followed), and 7 close-ended questions regarding nurses' basic characteristics (i.e., age, sex, degrees acquired, years of experience). The second part consisted of 3 open-ended questions aimed at investigating: modalities of integration in the practice's staff, list and description of activities performed in the practice by the nurse, personal considerations regarding the appropriateness of the received training or educational background.

The investigated variables were divided into 3 categories, according to the topic addressed: Institutional variables (relating to the surgery/clinic): the number of pediatricians and nurses/pediatric nurses; the type of practice (individual practice, group practice including two or more pediatricians working in a single location, associative practice including two or more pediatricians working in practices located throughout the territory but coordinating the opening hours of their practices to ensure greater availability of access to patients); and the number, age and ethnicity of the children followed;

Individual variables (relating to the nurses): socio-demographic characteristics; basic and subsequent training; length of service in the practice; type of contract; previous working experiences.

Organizational variables (relating to the activities carried out): the type of involvement and the activities carried out.

The organizational variables were divided into educational and technical macro-areas in line with the specific areas of intervention of nurses and pediatric nurses laid down in Art. 1, comma 2, of Ministerial Decrees No. 739/1994 and 70/1997 (Regolamento concernente l'individuazione 
della figura e del relativo profilo professionale dell'Infermiere, 1994; Regolamento concernente l'individuazione della figura e del relativo profilo professionale dell'Infermiere pediatrico, 2006). The educational interventions were further subdivided into activities of primary, secondary or tertiary prevention following the definition of the "Istituto Superiore della Sanità." Primary prevention aims to improve the overall health of the population; secondary prevention aims to detect a disease early or timely while tertiary prevention aims to reduce symptoms of the disease and improve quality of life (Rare Diseases Prevention, 2014). Any response not falling into one of the two macro-areas was recorded as "bureaucratic administrative/support activities."

Data analysis

The data were analyzed descriptively, with the continuous variables being recorded as mean values \pm standard deviation (SD) and ranges, and the discrete variables as percentages.

\section{RESULTS}

Out of the 424 primary care pediatricians registered with the Health Protection Agency of the Metropolitan City of Milan, only 40 employed nurses in the practice. The total number of nurses employed in these 40 practices was 28 . All of them were contacted to participate in the study: 22 nurses were enrolled, whereas 6 declined to participate.

\section{Institutional variables}

Three nurses (14\%) worked in three solo practices (three pediatricians); nine (41\%) in three group practices (14 pediatricians), ten (45\%) in six associative practices (15 pediatricians)

The mean number of children followed by the investigated practices was $1093.3 \pm 194$. Each child was clinically followed by the pediatrician, whose work was supported by the nurse. No nurse stated to be exclusively in charge of any patient.

Fifteen of the interviewed nurses $(68 \%)$ stated they saw children with various ethnic origins, and only seven (32\%) that they mainly saw Italian children.

\section{Individual variables}

The study sample consisted entirely of women with a mean age of $39 \pm 13.3$ years; $16(73 \%)$ 
were pediatric nurses. Twelve nurses (55\%) had a regional diploma, and $10(45 \%)$ a university degree. Irrespectively from the pre-service education received, all of the nurses stated that they had not received adequate basic training for working outside a hospital, but hardly any of them had attended further training courses.

All the enrolled nurses said they had been taken on as self-employed professionals. Fourteen (64\%) stated that they had not received any organized help in beginning their jobs; the remaining eight (36\%) were supported by another nurse for periods ranging from one week to one month.

In table 1 are shown the nurses' length of service in their current workplaces. The majority of nurses had been working in their current workplaces for less than 6 years.

\begin{tabular}{|l|l|l|}
\multicolumn{4}{|l|}{141} \\
\hline Years of experience in the practice \\
\hline Length of service & $\%$ & No. \\
\hline$<1$ & 31 & 7 \\
\hline $1-5$ & 41 & 9 \\
\hline $6-10$ & 14 & 3 \\
\hline$>10$ & 14 & 3 \\
\hline
\end{tabular}

Table 1: Nurses' length of service in their current workplaces

Moreover, fifteen nurses (68\%) had the previous working experience: six (40\%) had worked in a hospital, two (13\%) in the community setting, and seven (47\%) in both. The hospital activities were primarily carried out in a pediatric setting, and 11 in this group (73\%) had worked for more than 11 years.

\section{Organizational variables}

The nursing services offered by the practices were both of educational and technical nature.

The nurses also carried out bureaucratic administrative or support activities, depending on the type of practice.

\section{Educational interventions}

The nurses stated that the primary aims of their educational activities were to promote and 
preserve the children's health through primary, secondary, and tertiary interventions.

1

Table 2 shows their educational primary preventive interventions by type of practice.

\begin{tabular}{|l|l|l|l|}
\cline { 2 - 4 } \multicolumn{1}{c|}{} & \multicolumn{3}{|l|}{ Nurses that declared to be in charge of the topic } \\
\hline Type of Practice & $\begin{array}{l}\text { Exclusive or } \\
\text { complementary } \\
\text { breastfeeding }\end{array}$ & $\begin{array}{l}\text { Prevention of most } \\
\text { common childhood } \\
\text { diseases (i.e., } \\
\text { respiratory tract } \\
\text { infections) }\end{array}$ & $\begin{array}{l}\text { Parental training } \\
\text { courses }\end{array}$ \\
\hline $\begin{array}{l}\text { Solo practices' } \\
\text { nurses }\end{array}$ & $3(100 \%)$ & $2(67 \%)$ & $0(0 \%)$ \\
\hline $\begin{array}{l}\text { Group practices' } \\
\text { nurse }\end{array}$ & $8(89) \%$ & $4(44 \%)$ & $2(22 \%)$ \\
\hline $\begin{array}{l}\text { Associative } \\
\text { practices' nurses }\end{array}$ & $8(80 \%)$ & $5(50 \%)$ & $1(10 \%)$ \\
\hline $\begin{array}{l}\text { Total of interviewed } \\
\text { nurses }\end{array}$ & $19(86 \%)$ & $16(73 \%)$ & $3(14 \%)$ \\
\hline
\end{tabular}

Table 2: Educational interventions by type of practice. Results are listed as the number (percentage) of nurses who declared to be in charge of the topic as an educational activity.

The only secondary preventive intervention was hearing screening through a parental questionnaire, which was administered by four (44\%) nurses working in group practices and three $(30 \%)$ nurses working in associative practices. In table 3 are shown the 6 tertiary preventive interventions performed by nurses, by type of practice.

\begin{tabular}{|c|c|c|c|c|c|c|}
\hline \multirow[b]{2}{*}{$\begin{array}{l}\text { Type of } \\
\text { Practice }\end{array}$} & \multicolumn{6}{|c|}{ Nurses that declared to be in charge of the topic } \\
\hline & $\begin{array}{l}\text { Nasal } \\
\text { washes }\end{array}$ & $\begin{array}{l}\text { Management } \\
\text { of feverish } \\
\text { children }\end{array}$ & $\begin{array}{l}\text { Management } \\
\text { of cough and } \\
\text { sore throat }\end{array}$ & $\begin{array}{l}\text { Management } \\
\text { of vomiting } \\
\text { and diarrhea }\end{array}$ & $\begin{array}{l}\text { Management } \\
\text { of } \\
\text { exanthematous } \\
\text { diseases }\end{array}$ & $\begin{array}{l}\text { Management } \\
\text { of } \\
\text { conjunctivitis }\end{array}$ \\
\hline $\begin{array}{l}\text { Solo } \\
\text { practices' } \\
\text { nurses }\end{array}$ & $1(33 \%)$ & $3(100 \%)$ & $3(100 \%)$ & $3(100 \%)$ & $3(100 \%)$ & $3(100 \%)$ \\
\hline $\begin{array}{l}\text { Group } \\
\text { practices' } \\
\text { nurse }\end{array}$ & $8(89 \%)$ & $8(89 \%)$ & $9(100 \%)$ & $9(100 \%)$ & $8(89 \%)$ & $8(89 \%)$ \\
\hline $\begin{array}{l}\text { Associative } \\
\text { practices' } \\
\text { nurses }\end{array}$ & $9(90 \%)$ & $9(90 \%)$ & $9(90 \%)$ & $9(90 \%)$ & $9(90 \%)$ & $9(90 \%)$ \\
\hline $\begin{array}{l}\text { Total of } \\
\text { interviewed } \\
\text { nurses }\end{array}$ & $\begin{array}{l}18 \\
(82 \%)\end{array}$ & $20(91 \%)$ & $21(95 \%)$ & $21(95 \%)$ & $20(91 \%)$ & $20(91 \%)$ \\
\hline
\end{tabular}


Table 3: Tertiary preventive educational activity by type of practice. Results are listed as the number (percentage)

of nurses that declared to be in charge of the topic as a preventive educational activity.

All the nurses working in group practices said that they autonomously carried out

the educational activities shown in Table 4, whereas the nurses working in the seven individual practice's or associative practices did not do.

\begin{tabular}{|c|c|c|c|c|c|c|c|}
\hline \multirow[b]{2}{*}{$\begin{array}{l}\text { Educational } \\
\text { activity }\end{array}$} & \multirow[b]{2}{*}{$\begin{array}{l}\text { Total of } \\
\text { interviewed } \\
\text { nurses }\end{array}$} & \multicolumn{2}{|c|}{ Solo practices } & \multicolumn{2}{|c|}{ Group practices } & \multicolumn{2}{|c|}{ Associative practices } \\
\hline & & $\begin{array}{l}\text { Perform } \\
\text { ed with } \\
\text { doctor }\end{array}$ & $\begin{array}{l}\text { Perfor } \\
\text { med } \\
\text { autono } \\
\text { mously }\end{array}$ & $\begin{array}{l}\text { Performed } \\
\text { with doctor }\end{array}$ & $\begin{array}{l}\text { Performed } \\
\text { autonomo } \\
\text { usly }\end{array}$ & $\begin{array}{l}\text { Performed } \\
\text { with doctor }\end{array}$ & $\begin{array}{l}\text { Performed } \\
\text { autonomou } \\
\text { sly }\end{array}$ \\
\hline $\begin{array}{l}\text { Exclusive and } \\
\text { complementary } \\
\text { breastfeeding }\end{array}$ & $19(86 \%)$ & $\begin{array}{l}3 \\
(100 \%)\end{array}$ & $0(0 \%)$ & $0(0 \%)$ & $8(89 \%)$ & $8(80 \%)$ & $0(0 \%)$ \\
\hline $\begin{array}{l}\text { Prevention of } \\
\text { most common } \\
\text { childhood } \\
\text { diseases (i.e., } \\
\text { respiratory } \\
\text { tract infections) }\end{array}$ & $16(73 \%)$ & $2(67 \%)$ & $0(0 \%)$ & $0(0 \%)$ & $4(44 \%)$ & $5(50 \%)$ & $0(0 \%)$ \\
\hline $\begin{array}{l}\text { Parental } \\
\text { training courses }\end{array}$ & $3(14 \%)$ & $0(0 \%)$ & $0(0 \%)$ & $0(0 \%)$ & $2(22 \%)$ & $1(10 \%)$ & $0(0 \%)$ \\
\hline $\begin{array}{l}\text { Education } \\
\text { concerning } \\
\text { nasal washes }\end{array}$ & $18(82 \%)$ & $1(33 \%)$ & $0(0 \%)$ & $0(0 \%)$ & $8(89 \%)$ & $9(90 \%)$ & $0(0 \%)$ \\
\hline
\end{tabular}

Table 4: Educational activities performed by nurses according to the type of practice. Results are listed as the number (percentage) of nurses that declared to be in charge of the topic autonomously or in collaboration with the doctor.

In carrying out their tertiary preventive activities, 20 (91\%) of the interviewed nurses also gave telephone advice regarding the management of typical children's issues, such as fever, cough, vomiting, and diarrhea. Eleven (55\%) of the practices use algorithms as a guide to ensure that telephone calls are handled in a comprehensive and organized manner.

Only six (30\%) of the nurses giving telephone advice specified that they had been previously trained to do so and that their previous working experience had undoubtedly helped them to learn 
how to do it.

\section{Technical interventions}

The nurses also stated that they carried out the diagnostic/therapeutic activities listed in

Tables 5 and 6.

\begin{tabular}{|l|l|l|l|l|}
\hline Activity & Total & Solo practices & $\begin{array}{l}\text { Group } \\
\text { practices }\end{array}$ & $\begin{array}{l}\text { Associative } \\
\text { practices }\end{array}$ \\
\hline $\begin{array}{l}\text { Measuring } \\
\text { anthropometric } \\
\text { parameters }\end{array}$ & $\begin{array}{l}21 \\
(95 \%)\end{array}$ & $3(100 \%)$ & $9(100 \%)$ & $9(90 \%)$ \\
\hline Measuring vital signs & $\begin{array}{l}20 \\
(91 \%)\end{array}$ & $3(100 \%)$ & $8(89 \%)$ & $9(90 \%)$ \\
\hline $\begin{array}{l}\text { Level 1 investigations } \\
\text { (simple self-help) }\end{array}$ & $\begin{array}{l}22 \\
(100 \%)\end{array}$ & $3(100 \%)$ & $9(100 \%)$ & $10(100 \%)$ \\
\hline Electrocardiogram & $2(9 \%)$ & $0(0 \%)$ & $2(22 \%)$ & $0(0 \%)$ \\
\hline
\end{tabular}

${ }^{a}$ Level 1 investigations = pharyngeal swabs, hemochrome, C-reactive Protein,( PCR), glycemia, urine stick.

Table 5: Diagnostic activities

\begin{tabular}{|l|l|l|l|l|}
\hline Activity & Total & Solo practices & $\begin{array}{l}\text { Group } \\
\text { practices }\end{array}$ & $\begin{array}{l}\text { Associative } \\
\text { practices }\end{array}$ \\
\hline Vaccinations & $13(59 \%)$ & $2(67 \%)$ & $7(78 \%)$ & $4(40 \%)$ \\
\hline $\begin{array}{l}\text { Intramuscular } \\
\text { drug } \\
\text { administration }\end{array}$ & $\begin{array}{l}17 \\
(77 \%)\end{array}$ & $2(67 \%)$ & $9(100 \%)$ & $6(60 \%)$ \\
\hline Dressings & $\begin{array}{l}15 \\
(68 \%)\end{array}$ & $1(33 \%)$ & $9(100 \%)$ & $5(50 \%)$ \\
\hline Removing sutures & $\begin{array}{l}13 \\
(59 \%)\end{array}$ & $1(33 \%)$ & $8(89 \%)$ & $4(40 \%)$ \\
\hline
\end{tabular}

Table 6: Therapeutic activities

Three (14\%) of the nurses working in group practices followed the progress of the children with chronic conditions autonomously, by measuring the vital and anthropometric parameters and carrying out educational activities.

Finally, Table 7 shows the bureaucratic administrative/support activities carried out in the different types of practices.

\begin{tabular}{|l|l|l|l|l|}
\hline Activity & Total & Solo practices & $\begin{array}{l}\text { Group } \\
\text { practices }\end{array}$ & $\begin{array}{l}\text { Associative } \\
\text { practices }\end{array}$ \\
\hline Opening/closing practice & $\begin{array}{l}10 \\
(45 \%)\end{array}$ & $3(100 \%)$ & $1(11 \%)$ & $6(60 \%)$ \\
\hline $\begin{array}{l}\text { Distributing } \\
\text { certificates/prescriptions }\end{array}$ & $7(32 \%)$ & $2(67 \%)$ & $2(22 \%)$ & $3(30 \%)$ \\
\hline Invoicing & $2(9 \%)$ & $1(33 \%)$ & $1(11 \%)$ & $0(0 \%)$ \\
\hline
\end{tabular}




\begin{tabular}{|l|l|l|l|l|} 
Managing appointments & $\begin{array}{l}10 \\
(45 \%)\end{array}$ & $3(100 \%)$ & $2(22 \%)$ & $5(50 \%)$ \\
\hline Computer management & $\begin{array}{l}17 \\
(77 \%)\end{array}$ & $3(100 \%)$ & $6(67 \%)$ & $8(80 \%)$ \\
\hline Waiting room management & $\begin{array}{l}11 \\
(50 \%)\end{array}$ & $3(100 \%)$ & $2(22 \%)$ & $6(60 \%)$ \\
\hline Receiving telephone calls & $7(32 \%)$ & $3(100 \%)$ & $0(0 \%)$ & $4(40 \%)$ \\
\hline $\begin{array}{l}\text { Printing information } \\
\text { materials }\end{array}$ & $\begin{array}{l}11 \\
(50 \%)\end{array}$ & $2(67 \%)$ & $5(55 \%)$ & $4(40 \%)$ \\
\hline $\begin{array}{l}\text { Checking expiry dates of } \\
\text { drugs/devices }\end{array}$ & $\begin{array}{l}20 \\
(91 \%)\end{array}$ & $3(100 \%)$ & $9(100 \%)$ & $8(80 \%)$ \\
\hline Material supplies & $\begin{array}{l}18 \\
(82 \%)\end{array}$ & $3(100 \%)$ & $9(100 \%)$ & $6(60 \%)$ \\
\hline Managing special waste & $\begin{array}{l}15 \\
(68 \%)\end{array}$ & $2(67 \%)$ & $8(89 \%)$ & $5(50 \%)$ \\
\hline
\end{tabular}

Table 7: Bureaucratic administrative/support activities.

\section{DISCUSSION}

The results provide a clear and exhaustive description of nurses' activities, and show that the areas covered are in line with their professional profile, (Regolamento concernente l'individuazione della figura e del relativo profilo professionale dell'Infermiere, 1994; Regolamento concernente l'individuazione della figura e del relativo profilo professionale dell'Infermiere pediatrico, 2006) the deontological code (Code of ethics of the nurse, 2009) and other published findings (Bauer \& Bodenheimer, 2017). The role of primary care nurses is commonly linked to areas of education and inter-relationships, aimed at promoting healthy lifestyles and the treatment compliance of patients with chronic diseases (Bauer \& Bodenheimer, 2017). However, our study of pediatric practices, demonstrated that their purpose is not limited to promoting the health of children and their families by dealing with matters concerning disease management and prevention. In fact, they also have a proactive and autonomous role in performing diagnostic and therapeutic activities.

However, the realities of working in pediatric practices are even more varied, and working in smaller contexts in which there are few pediatricians (if not only one) may give rise to some issues. In fact, there is a difference between nurses' responses regarding educational interventions autonomously performed (table 4) and therapeutic activities (table 6) in individual and group practices, with the latter being more involved in these tasks. The activities of a practice depend on its organizational structure, and it could be speculated that the higher prevalence of bureaucratic 
administrative/support activities in solo practices (Table 7), may pose a barrier to nurses' more advanced and proactive role (Wilson et al., 2002).

Group practices allow nurses to carry out professional activities autonomously and develop new organizational initiatives. They are more likely to underline the role of collaboration and the subdivision of healthcare activities, thus allowing nurses to make the most of their professional skills, training, and career prospects. A shared vision and teamwork make it possible to establish and maintain collaborative relationships between pediatricians and nurses, as has also been pointed out by Hamel and Vossing (Hämel \& Vössing, 2017).

Two studies carried out in Catalonia have shown that nurses can autonomously manage minor pathological conditions. One found that $75.6 \%$ of 54,379 consultations involving pediatric patients led to the successful resolution of minor diseases and low reoccurrence rates during the following seven days (Fabrellas et al., 2011). The other (Fabrellas et al., 2015) was an observational study of 467,160 unscheduled nursing consultations involving children with minor diseases were successfully resolved in $65.4 \%$ of cases; the remaining $34.6 \%$ were referred to a pediatrician based on the nurses' evaluation. These results show the feasibility of using algorithms and close collaboration between physicians and nurses and highlight the effectiveness of nurse-led patient management. In our study, only 55\% of nurses used algorithms to evaluate patients during telephone calls and decided whether to refer them to the doctor. Despite the majority of nurses (91\%) indicated they provided advise on minor children's illnesses, only $30 \%$ stated to have received specific training to give telephone advice or felt that their previous clinical experience was sufficient to enable them to provide clinical advise.

Nevertheless, within our context, it has to be taken into account that there are no predefined algorithms or structured tabs for pediatric nurses working in primary care in Italy. Moreover, according to our national law (Regolamento concernente l'individuazione della figura e del relativo profilo professionale dell'Infermiere,1994), pediatric nurses are not allowed for independent clinical intervention to manage children's illnesses. Any decision or final 
evaluation of the patient, including general examination, diagnosis, and therapeutic prescription, should be performed by the doctor, leaving only a supportive role for nurses in clinical or therapeutic decisions.

Horrocks and Creazzo have also found that professional specialization (73\% of our interviewees were pediatric nurses) or previous experience of working in a hospital (mainly a pediatric hospital) are capable of guaranteeing that children and adolescents are provided with appropriate healthcare services (Horrocks et al., 2002; Creazzo \& Vagliano, 2012). As in the case of previously reported studies, (Dierick-van Daele et al., 2009; Fabrellas et al., 2011) we found that even telephone consultations concerning health problems seem to valorize professional specificity. Moreover, nurses reported using algorithms developed in collaboration with a pediatrician during telephone consultations in 55\% of the present study's practices. Within this context, it can be therefore speculated that the associated use of algorithms might represent an additional tool in guiding nurses when defining the need for an urgent or programmed visit, giving advice, or ensuring an appropriate follow-up.

However, our interviews also highlighted some critical factors concerning the basic training received by nurses. Regardless of their background or type of education (a regional diploma or university degree), all the interviewed nurses stated they had not received adequate basic training for working outside a hospital. Nearly any of them had attended further training courses. These results indicate the need for implementing further specific training.

Various published articles (Horrocks et al., 2002; Thomas \& Laurie, 2016) have suggested that providing specific training aimed at integrating nursing knowledge and skills in the primary care setting seems to be a priority. They all agree that there is a need to create specific primary care training courses for nurses and, undefined nature of such training, that these should be based on shared protocols (Hämel \& Vössing, 2017; Bauer \& Bodenheimer, 2017) in order to guarantee the safety and efficacy of nursing interventions (Norful et al., 2017) and also reduce the number of 
273 requests for subsequent further action on the part of surgical centers and clinics (Fabrellas et al., 1 2ิ74 2015).

\section{PRACTICE IMPLICATIONS}

The findings of this study underline the potential of developing the nursing profession at the community level. By highlighting the need of an adequate basic training, nurses could request and benefit from optional college classes or post-graduate courses organized by national or local nursing associations. Moreover, nursing organizations could draft and discuss standards of practice, to create shared operational guidelines to which primary care nurses can refer, as already done in hospital settings.

In order to make the most of their professional skills, nurses are entitled to have a proactive and autonomous role in performing educational, diagnostic and therapeutic activities. To encourage these changes, a more structured primary-care oriented education and training would enable nurses who choose to work in these settings to seek out employment opportunities that enable more autonomy and independence in their role and practice collaboration.

\section{LIMITATIONS}

The limitations of this study are attributable to the small sample size and the fact that it was restricted to the Health Protection Agency of the Metropolitan City of Milan, which means that the findings cannot be generalized to what nurses may do in other primary care pediatric settings.

\section{CONCLUSION}

The present study results allow for a better understanding of the nurses' working activities within the primary care system. Further studies are desirable to extend the investigation of the pediatric nurses' activities implemented at the community level. 
300 List of abbreviations:

\section{ACKNOWLEDGMENTS}

Funding: This research did not receive any specific grant from funding agencies in the public, commercial, or not-for-profit sectors.

Competing interests: The authors declare they have no competing interests

\section{Ethics approval and consent to participate}

Protocol was approved by the institutional Ethics Committee of the Fondazione Istituto di

Ricovero e Cura a Carattere Scientifico Ca’ Granda Ospedale Maggiore Policlinico, Milan.

Informed written consent was obtained from the participants before enrolment.

Data statement: Due to the sensitive nature of the questions asked in this study, survey respondents were assured that raw data would remain confidential and would not be shared.

Acknowledgments: We thank all the nurses and the Primary Care Pediatricians who took part in the study.

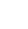

(1)

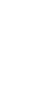

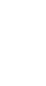

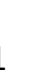

2

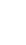

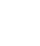




\section{REFERENCES}

Asvall, J.E. (2000). Health for all in the 21 st century a policy framework for the WHO European region. Int J Occup Med Environ Health, 13(1):5-13.

Accordo Collettivo Nazionale per la disciplina dei rapporti con i medici specialistici

Pediatri di libera scelta, ai sensi dell'art. 8 del Decreto Legislativo 502/92 come modificato dai Decreti Legislativi n. 517/93 e n. 229/99. (2001)

https://www.medicoeleggi.com/argomenti00/italia2/12875.html/ Accessed 12 July 2016.

Bauer, L., Bodenheimer, T. (2017). Expanded roles of registered nurses in primary care delivery of the future. Nurs Outlook. https://doi:10.1016/j.outlook.2017.03.011

Code of ethics of the nurse. (2009).

https://opi.roma.it/archivio_news/pagine/15/Codice\%20Deontologico\%202009.pdf/. Accessed 3 September 2016.

Creazzo, C., Vagliano, L. (2012). L'infermiere pediatrico e territorio: potenzialità e prospettive. Child Nurses Ital J Pediatr Nurs Sci, 4(4):112 -117.

Decreto Ministeriale 14 settembre 1994, n.739. Regolamento concernente l'individuazione 
della figura e del relativo profilo professionale dell'Infermiere. (1994)

http://www.salute.gov.it/imgs/C_17_normativa_1870_allegato.pdf/ Accessed 12 July 2016.

Decreto ministeriale 17 gennaio 1997, n.70. Regolamento concernente l'individuazione della figura e del relativo profilo professionale dell'Infermiere pediatrico. (2006). https://www.fnopi.it/archivio_news/leggi/177/DM170197n70.pdf/ Accessed 12 July 2016.

Dierick-van Daele, A., Metsemakers, J., Derckx, E., Spreeuwenberg, C., Vrijhoef, H. (2009). Nurse practitioners substituting for general practitioners: randomized controlled trial. Journal of Advanced Nursing, 65(2):391-401.

Diego Van Esso, D., Del Torso, S., Hadjipanayis, A., Biver, A., Jaeger-Roman, E., Wettergren, B., Nicholson, A. and the members of the Primary- Secondary Working Group (PSWG) of the European Academy of Paediatrics (EAP). (2010). Paediatric primary care in Europe: variation between countries. Arch Dis Child, 95:791-795.

Document of the Conference of Regions. The White Book on children's health 2011. (2012). http://www.regioni.it/news/2012/01/31/sip-libro-bianco-2011-la-salute-dei-bambini-luci-eombre-240001/. Accessed 11 July 2016

Fabrellas, N., Vidal, A., Amat, G. (2011). Nurse management of "same day" consultation for patients with minor illnesses: results of an extended programme in primary care in Catalonia. J Adv Nurs. https://doi: 10.1111/j.1365-2648.2011.05624.x

Fabrellas, N., Juvé, E., Solà, M., et al. (2015) A Program of Nurse Management for Unscheduled 
Consultations of Children With Acute Minor Illnesses in Primary Care. J Nurs Scholarsh, 47(6):529-535. doi:10.1111/jnu.12169

Horrocks, S., Anderson, E., Salisbury, C. (2002). Systematic review of whether nurse practitioners working in primary care can provide equivalent care to doctors. $B M J, 324(7341): 819-23$. https://doi: 10.1136/bmj.324.7341.819

Hämel, K., Vössing, C. (2017). The collaboration of general practitioners and nurses in primary care: a comparative analysis of concepts and practices in Slovenia and Spain.

Prim Health Care Res Dev. https://doi:10.1017/S1463423617000354

Il sistema delle cure primarie. (2003).

http://www.salute.gov.it/portale/temi/p2_6.jsp?id=496\&area=Cure20primarie\&menu=cure/ Accessed 11 July 2016.

Kooienga, S.A., Carryer, J.B. (2015) Globalization and advancing primary health care nurse practitioner practice. Journal of Nurse Practitioner, 11(8):804- 11.

Laurant, M., Reeves D., Hermens, R., Braspenning, J., Grol, R., Sibbald, B. (2005). Substitution of doctors by nurses in primary care. Cochrane Database of Systematic Reviews. https://doi: 10.1002/14651858.CD001271.pub2

Le cure primarie nel nuovo assetto organizzativo e funzionale del SSN, Pubblicazione a cura di Fondazione Sicurezza in Sanità $-8^{\circ}$ Forum Risk Management in Sanità. Arezzo. (2013) http://www.fondazionesicurezzasanita.it/index.php/pubblicazioni/ Accessed 12 July 2016. 
Laurant, M., Van der Biezen, M., Wijers, N., Watananirun, K., Kontopantelis, E., Van Vught, A.J.A.H. (2018) Nurses as substitutes for doctors in primary care. Cochrane Database of Systematic Reviews. doi: 10.1002/14651858.CD001271.pub3

Marinello, R., Scarazatti, M. (2011). La salute del bambino e dell'adolescente. (1st ed.) Pisa: ETS Edizioni, (p.173-8).

Martínez-González, N.A., Djalali, S., Tandjung, R., et al. (2014). Substitution of physicians by nurses in primary care: a systematic review and meta-analysis. BMC Health Serv Res. https://doi:10.1186/1472-6963-14-214

Martínez-González, N.A., Rosemann, T., Tandjung, R., Djalali, S. (2015). The effect of physician nurse substitution in primary care in chronic diseases: a systematic review. Swiss Med Wkly. https://doi: 10.4414/smw.2015.14031

Norful, A., Martsolf, G., DeJacq, K., Poghosyan, L. (2017). Utilization of Registered Nurses in Primary Care Teams: A Systematic Review. Int J Nurs Stud. https://doi:10.1016/j.ijnurstu.2017.05.013

Rare Disease National Center. Rare Diseases Prevention. (2014). http://www.iss.it/cnmr/index.php?lang=1\&id=2473\&tipo=77/ Accessed 3 September 2016.

Rocco, G., Marcadelli, S., Stievano, A., Cipolla, C. (2017). L'Infermiere di Famiglia e di Comunità. Proposte di policy per un nuovo welfare. (1st ed). Milano: Franco Angeli.

The European Health Report 2012: Charting the way to well-being. (2012). 
428 http://www.euro.who.int/_data/assets/pdf_file/0004/197113/EHR2012-Eng.pdf/ Accessed 11 429 July 2016.

4

431 Thomas, B., Laurie, B. (2016). Rethinking the Primary Care Workforce- An Expanded Role for 8 ${ }_{1}^{9} 432$ Nurses. $N$ Engl J Med. https://doi: 10.1056/NEJMp1606869

Wilson, A., Pearson, D., Hassey, A. (2002). Barriers to developing the nurse practitioner role in Primary care - the GP perspective. Fam Prac. https://doi: 10.1093/fampra/19.6.641

Würtz, G.M.F., Jensen, C.S., Egerod, I. (2019). International perspectives on the pediatric nurse practitioner role. J Am Assoc Nurse Pract, 31(12):773-781.

doi:10.1097/JXX.0000000000000252 